\title{
Population Dynamics of Estuarine Amphipods in Cochin Backwaters
}

\author{
K. K. C. Nair, T. C. Gopalakrishnan, P. Venugopal, M. George Peter, \\ K. V. Jayalakshmi and T. S. S. Rao*
}

National Institute of Oceanography, Regional Centre, Cochin-682 018, India

\begin{abstract}
Population dynamics of 11 gammarid amphipod species (belonging to 9 genera), collected from Cochin backwaters, have been studied for the first time, based on an year round collection. The species are: Corophium triaenonyx Stebbing, Photis digitata Barnard, Grandidierella gilesi Chilton, Melita zeylanica Stebbing, Eriopisa chilkensis (Chilton), Quadrivisio bengalensis Stebbing, Grandidierella bonnieri Stebbing. Cheiriphotis megacheles Walker, Ampelisca zamboangae Stebbing, Perioculodes longimanus (Bate and Westwood) and Ampelisca cyclops Walker The highly varying salinities ( 0 to $36.20 \%$ S) are one of the major limiting factors which govern the numerical density and species diversity of these gammarid populations. Except for the 3 high-saline species $A$. zamboangae, $A$. cyclops and $P$. longimanus, which are recorded during late January, all other species contribute substantially to the ecosystem. $C$. megacheles and $G$. bonnieri are estuarine and failed to establish themselves. $C$. triaenonyx is the most widespread species inhabiting all stations with maximum numerical abundance. The coefficient of correlation of different groups with temperature, salinity, dissolved oxygen, $\mathrm{C} / \mathrm{N}$ ratio and phosphorus revealed that representatives of the families Ampeliscidae. Gammaridae and Photidae are negatively correlated with salinity. Members of the family Corophidae showed some positive correlation with salinity. None of the groups exhibited significant correlation with temperature or with dissolved oxygen. The effect of temperature, salinity and dissolved oxygen on the production of gammarid amphipods was studied by multiple regression analysis. Salinity was found to be the prominent factor controlling the abundance of gammarid amphipods, followed by temperature and dissolved oxygen. The fitted regression was found to be significant at the $1 \%$ level $(\mathrm{P}<0.01)$ only for Station 1 .
\end{abstract}

\section{INTRODUCTION}

The backwaters of Cochin (Lat. $9^{\circ} 5^{\prime}$ to $10^{\circ} \mathrm{N}$, Long. $76^{\circ} 15^{\prime}$ to $76^{\circ} 20^{\prime}$ E) - a bar-built tidal estuary which is the northern extension of the Vembanad lake along the Kerala coast - have received much attention in recent years. Considerable work was done on hydrography, productivity, sedimentary characteristics and chemical aspects of this highly productive system. However, no information is available on the ecology and population dynamics of gammarid amphipods, a major constituent of the benthic community. The present paper presents and discusses data on major hydrographic features and population dynamics of 11 species of gammarid amphipods recorded for $1 \mathrm{yr}$.

\footnotetext{
- Present address: National Institute of Oceanography, Dona Paula, Goa 403 004, India
}

\section{MATERIAL AND METHODS}

Mud and bottom water were sampled at 5 fixed stations around Cochin Harbour (Fig. 1) from September 1975 to August 1976. The depth of the stations varied from 2 to $5 \mathrm{~m}$, Stations 1 and 2 being deepest. Bottom sediments were mostly silt and clay at Station 1. At Stations 2 and 4 , sediments comprised mostly silt and debris of fresh-water and terrigenous origin. Stations 3 and 5 were characterized mostly by fine sand. The mud samples were collected in triplicate by a Van Veen grab (area $0.048 \mathrm{~m}^{2}$ ) and water samples were taken with a 'Hytech' PVC water sampler. Mud samples were sieved through a $300 \mu \mathrm{m}$ screen and preserved for analysis in $4 \%$ formaldehyde. From these samples gammarid amphipods were separated, identified and counted in the laboratory. Densities per $\mathrm{m}^{2}$ were computed (Fig. 2, Table 1). Fig. 2 gives the numerical abundance (log values of numbers $\mathrm{m}^{2}$ ) of the 6 


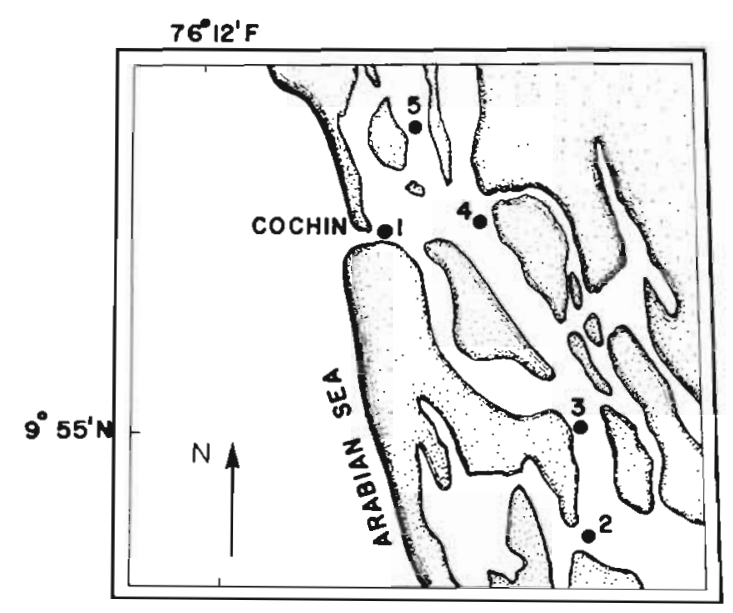

Fig. 1. Location of Stations 1 to 5 dominant species and Table 1 gives the actual numbers of the remaining 5 species which were less abundant. Salinity and oxygen were measured by the methods described in Strickland and Parsons (1968).

To study the coexistence of different species over space correlation coefficient matrix between species was formed (Table 2).

For each station a multiple regression model for the prediction of gammarid amphipods was developed, numerical abundance being correlated with temperature, salinity and dissolved oxygen. The fitted regression model is $y=b_{0}+b_{1} x_{1}+b_{2} x_{2}+b_{3} x_{3}$, where $y=$ number of individuals for all families together; $\mathrm{x}_{1}=$ temperature; $\mathrm{x}_{2}=$ salinity; $\mathrm{x}_{3}=$ dissolved oxygen . The model was fitted with the data by the method of least squares and normal equations were solved by

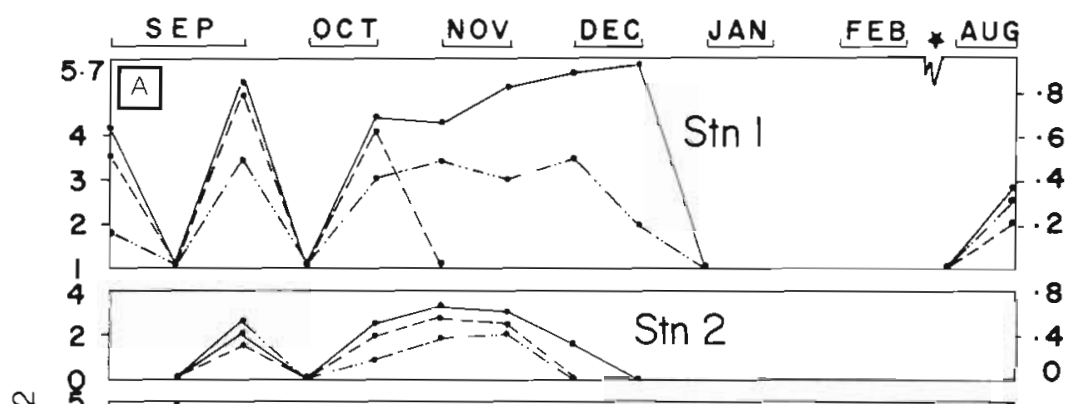

IE 3

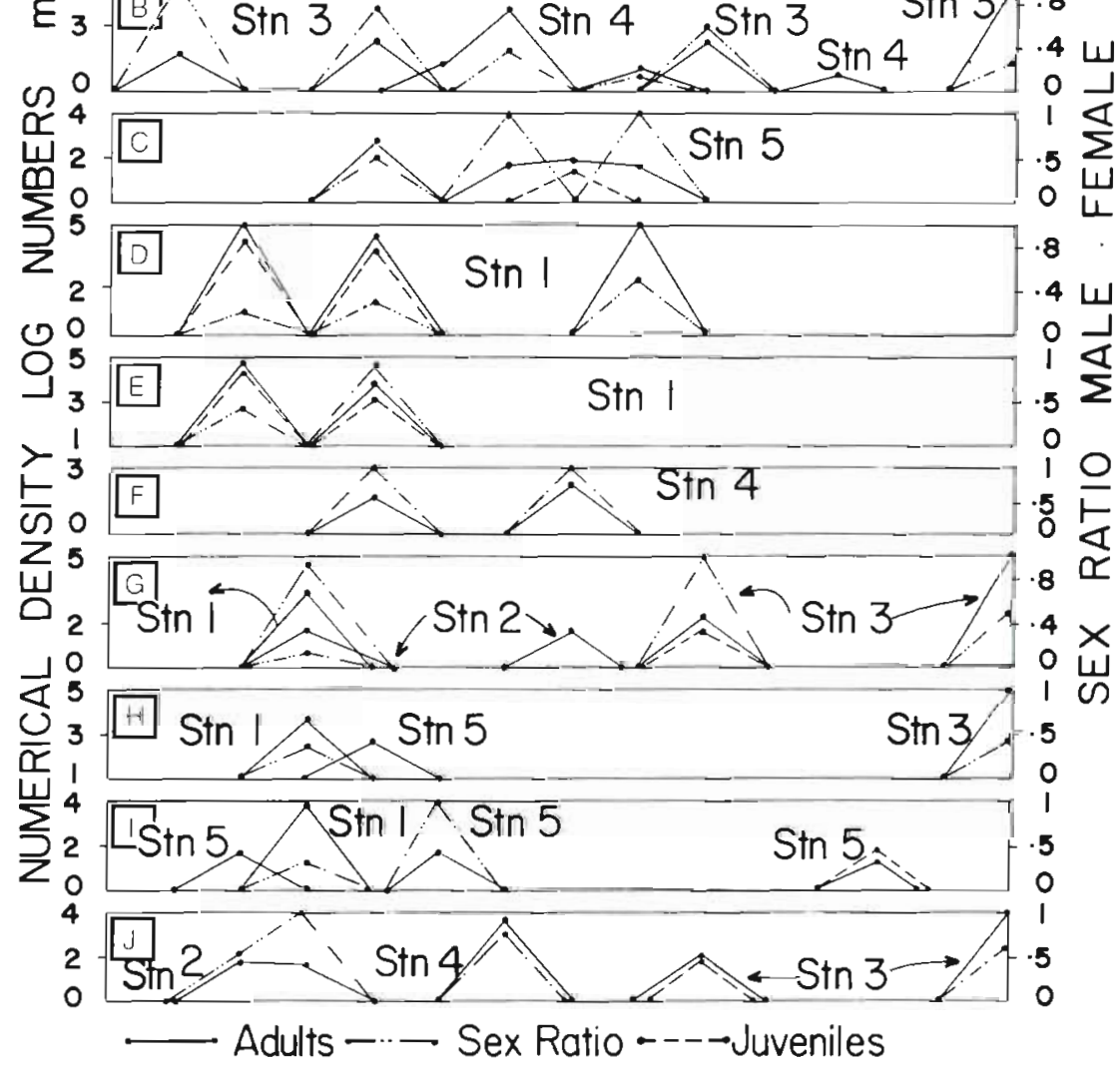

* NO GAMMARIDS FROM II-3-76TO 9-8-1976
Fig. 2. Numerical density $\mathrm{m}^{-2}$ (log values) of the more dominant species. A to $C: C$. triaenonyx; $\mathrm{D}: P$. digitata; E and F: G. gilesi, G: M. zeylanica; $\mathrm{H}$ : E. chilkensis; I and J: $Q$. bengalensis 
Fig. 3 ( 1 to 5): Environmental conditions at Stations 1 to 5 . S: bottom salinity $(\% \mathrm{~S})_{i}$ T: temperature $\left({ }^{\circ} \mathrm{C}\right) ; \mathrm{O}$ : oxygen $\left(\mathrm{ml} \mathrm{l}^{-1}\right.$; $X$ : percentage contribution of C. triaenonyx (A), P. digitata (B), G. gilesi (C), M. zeylanica (D), E. chilkensis (E), Q. bengalensis (F), G. bonnieri (G), C. megacheles $(\mathrm{H})$, A. zamboangae (I), P. longimanus (J), A. cyclops (K)
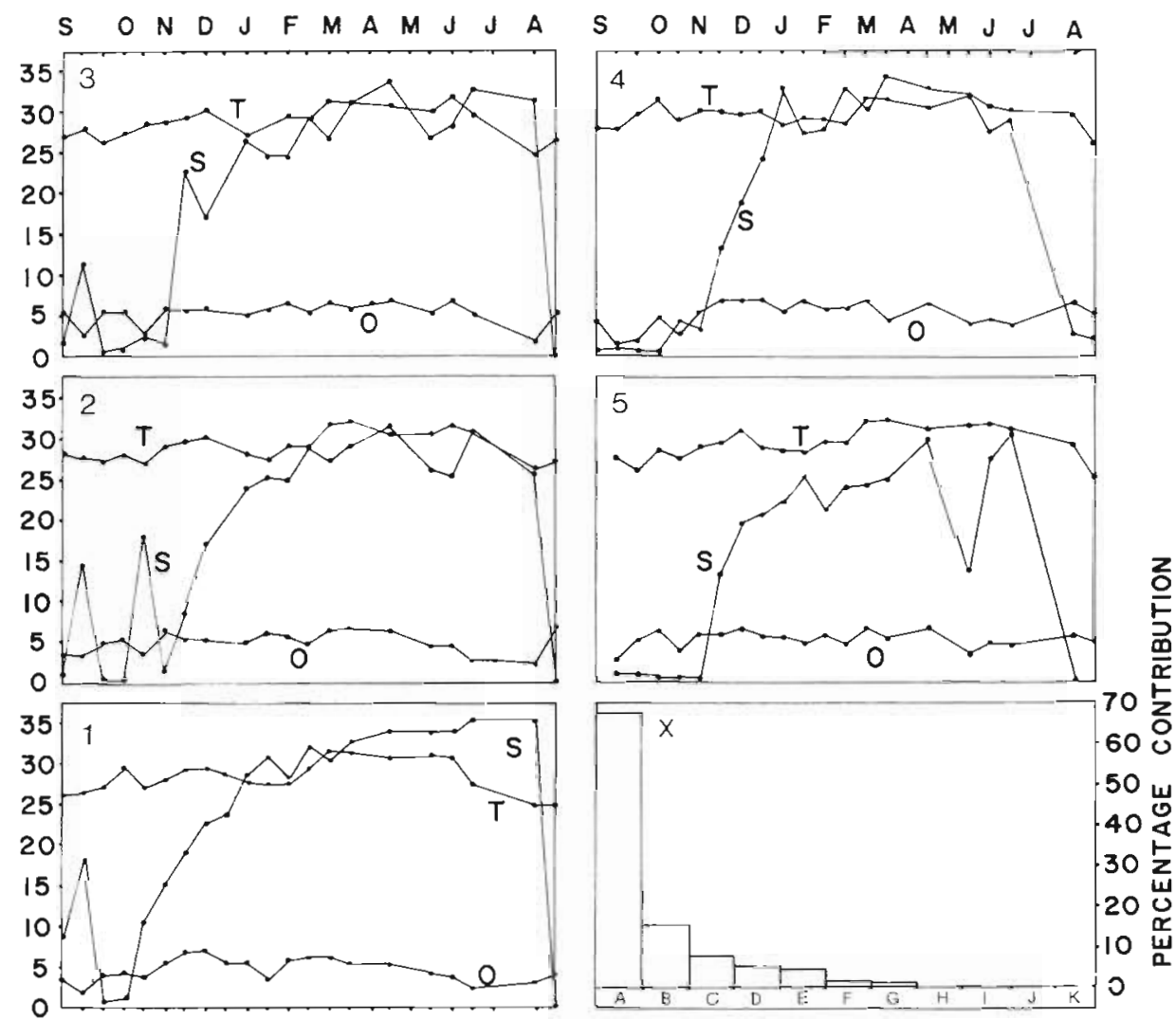

matrix inversion method. The solutions are the estimates of the regression coefficients $b_{0}, b_{1}, b_{2}$ and $b_{3}$. The significance of fitted regression was tested using analysis of variance technique; results are presented in Table 3 . The relative importance of each of the variables mentioned in the prediction equation was calculated using the formula

$$
/ \mathrm{bi} / \sqrt{\frac{\sum \mathrm{x}_{1}^{2}}{\sum \mathrm{y}^{2}}}
$$

(Snedecor and Cochran, 1967) (Table 4).

Species diversity index was calculated for each station using Fishers species diversity index $\left(S=a \log _{e}\right.$ $\left(1+\frac{N}{\alpha}\right) D$; where $S=$ no. of species; $N=$ number of individuals; $\alpha=$ Fishers species diversity index; variance of $\alpha$ was also calculated using the formula Fisher etal.(1943):

$$
V(\alpha)=\frac{\alpha^{3}\left[(N+\alpha)^{2} \log _{e}\left(\frac{2 N+\alpha}{N+\alpha}\right)-\alpha N\right]}{(S N+S \alpha-N \alpha)^{2}}
$$

\section{RESULTS AND DISCUSSION}

Ampelisca zamboangae Stebbing, A. cyclops Walker (Family-Ampeliscidae), Perioculodes longimanus (Bate and Westwood) (Family-Oedicerotidae), Eriopisa chilkensis (Chilton), Quadrivisio bengalensis Stebbing, Melita zeylanica Stebbing (Family-Gammaridae), Grandidierella gilesi Chilton, G. bonnieri Stebbing, Corophium triaenonyx Stebbing (Family-

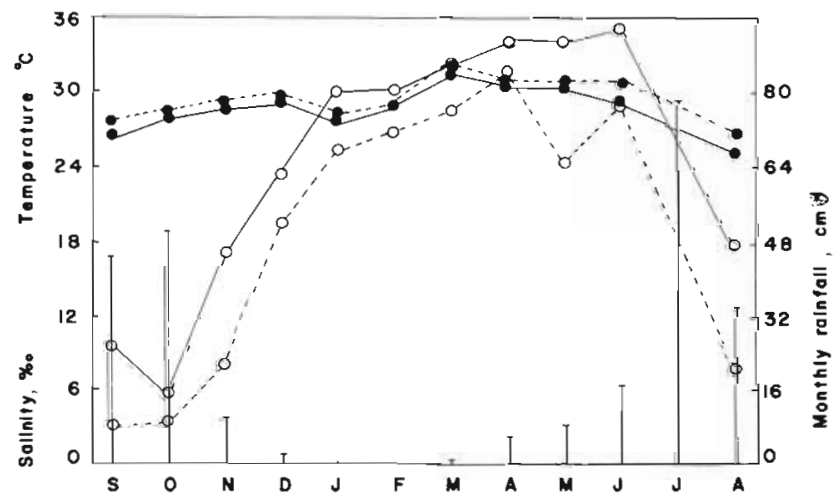

Fig. 4. Average monthly salinity, temperature and rainfall in the area investigated. Open circles: salinity; closed circles: temperature; dotted lines: estuary, straight lines: barmouth

Corophidae), Cheiriphotis megacheles Walker and Photis digitata Barnard (Family: Photidae) were recorded from the area investigated. The percentage contribution (Fig. 3: X) of various species to total numbers indicate that $C$. triaenonyx contributed the max- 
Table 1. Population data on gammarids, other than those in Fig. 2, at the stations examined in Cochin backwaters. Sept. 1975 to Aug. 1976

\begin{tabular}{|c|c|c|c|c|c|c|}
\hline Date & Species & $\begin{array}{l}\text { Station } \\
\text { No. }\end{array}$ & $\begin{array}{l}\text { Adults } \\
\left(\text { No } \mathrm{m}^{-2}\right)\end{array}$ & $\begin{array}{c}\text { Sex ratio } \\
\text { Male/female }\end{array}$ & $\begin{array}{l}\text { Juveniles } \\
\left({\left.\text { No } \mathrm{m}^{-2}\right)}^{-}\right.\end{array}$ & Remarks \\
\hline $27-11-1975$ & Cheiriphotis megacheles & 1 & 4167 & 3.00 & - & Absent at Stns. 2 to 5 \\
\hline $9-12-1975$ & Grandidierella bonnieri & 1 & 4688 & 2.00 & 3125 & Absent at Stns. 2 to 5 \\
\hline $27-1-1976$ & Ampelisca zamboangae & 1 & 21 & 0.17 & - & Absent at Stris. 2 to 5 \\
\hline $9-2-1976$ & Ampelisca zamboangae & 4 & 25 & 5.25 & - & Absent at Stns. 1 to $3 \& 5$ \\
\hline $27-1-1976$ & Perioculodes longimanus & 1 & 21 & 0.11 & - & Absent at Stns. 2 to 5 \\
\hline $27-1-1976$ & Ampelisca cyclops & 1 & 21 & 0.31 & - & Absent at Stns. 2 to 5 \\
\hline
\end{tabular}

Table 2. Correlation matrix for gammarid amphipods in Cochin backwaters

\begin{tabular}{|c|c|c|c|c|c|c|c|c|c|c|c|}
\hline & I & II & III & IV & $\mathrm{V}$ & VI & VII & VIII & IX & $\mathrm{x}$ & XI \\
\hline I & 1 & $0.9979^{\circ}$ & $0.9979^{\circ}$ & $0.9980^{\circ}$ & $0.9980^{\circ}$ & 0.5024 & $0.9980^{\circ}$ & $0.9980^{\circ}$ & -0.1252 & 0.2096 & -0.1640 \\
\hline II & & 1 & $0.9999^{\circ}$ & $1.0000^{\circ}$ & $1.0000^{\circ}$ & 0.5204 & $1.0000^{\circ}$ & $1.0000^{\circ}$ & -0.1879 & 0.1510 & -0.2262 \\
\hline III & & & 1 & $0.9999^{\circ}$ & $0.9999^{\circ}$ & 0.5220 & $0.9999^{\circ}$ & $0.9999^{\circ}$ & -0.1885 & 0.1510 & -0.2269 \\
\hline IV & & & & 1 & $1.0000^{\circ}$ & 0.5204 & $1.0000^{\circ}$ & $1.0000^{\circ}$ & -0.1879 & 0.1509 & -0.2262 \\
\hline V & & & & & 1 & 0.5204 & $1.0000^{\circ}$ & $1.0000^{\circ}$ & -0.1879 & 0.1510 & -0.2262 \\
\hline VI & & & & & & 1 & 0.5204 & 0.5204 & -0.3777 & 0.1510 & -0.2262 \\
\hline VII & & & & & & & 1 & $1.0000^{\circ}$ & -0.1879 & 0.1510 & -0.2262 \\
\hline VIII & & & & & & & & 1 & -0.1879 & 0.5090 & -0.2262 \\
\hline IX & & & & & & & & & 1 & 0.8769 & $-0.9992^{\circ}$ \\
\hline$x$ & & & & & & & & & & 1 & 0.8636 \\
\hline $\mathrm{XI}$ & & & & & & & & & & & 1 \\
\hline \multicolumn{12}{|c|}{$\begin{array}{l}\text { I Corophium triaenonyx, II Grandidierella bonnieri, III Grandidierella gilesi, IV Cheiriphotis megacheles, V Photis digitata, } \\
\text { VI Ampelisca zamboangae, VII Ampelisca cyclops, VIII Perioculodes longimanus, IX Eriopisa chilkensis, X Quadrivisio } \\
\text { bengalensis, XI Melita zeylanica. } \\
\text { r significant at the } 0.1 \% \text { level }(\mathrm{P}<0.001)\end{array}$} \\
\hline
\end{tabular}

imum $(67 \%)$ and $A$. cyclops and $P$. longimanus the least $(<0.0013 \%)$.

Temperature, salinity and oxygen of the bottom at the different stations are given in (Fig. 3: 1 to 5). Fig. 4 shows monthly rainfall data in and around Cochin and their effect on salinity over the period of observation. The environmental parameters revealed good correlation with onset, duration and intensity of the monsoon. The annual cycle of seasonal variations in Cochin backwaters is well documented (Qasim and Gopinathan, 1969; Nair and Tranter, 1971; Haridas et al., 1973). During monsoon periods in general, Cochin backwaters had low salinity, low temperature and high dissolved oxygen values while pre-monsoon periods were characterised by an increase in salinity and temperature and a decrease in oxygen content. The post monsoon season was the period of transition during which salinity and temperature gradually increased. Salinity and all other environmental features measured were subject to considerable variation throughout the observation (Fig. 3: 1 to 5). The development of the amphipod populations in the area of investigation (Fig. 2, Table 1) occurred during the late monsoon and post monsoon seasons (August-December) when low to median levels of salinity were recorded at the diffe- rent stations. The variations in the amphipod population with the increase in salinity indicate that salinity is of considerable importance in controlling amphipod population dynamics in the system studied (Table 1, Figs. 2 and 3).

At Station 1 all 11 species were present. Near the barmouth, this Station comprised both estuarine and marine species. Table 5 gives the ranges in salinity and temperature of the more dominant species and shows their correlation with lower and median salinities. All species that substantially contribute to the amphipod population may be regarded as estuarine, thriving at lower and median salinities with the exception of Ampelisca zamboangae. This species preferred high salinities and penetrated some distance into the estuary; it was recorded at Station 4 during the high saline period (Table 1, Figs. 2 and 3: 4). Cheiriphotis megacheles, considered to be estuarine, failed to establish itself; it was recorded only once in polyhaline water at Station 1. Grandidierella bonnieri, reported to be common in the estuaries of the east coast of India, was recorded only once also at Station 1 (December). Perioculodes longimanus, Ampelisca cyclops and A. zamboangae, reported to be marine, were present at Station 1 during the high- 
Table 3. Anova table for testing the significance of the fitted regression model at the 5 stations

\begin{tabular}{|c|c|c|c|c|c|}
\hline & Source & SS & $\mathrm{DF}$ & MSS & $\mathrm{F}^{\cdot}$ \\
\hline \multirow{4}{*}{$\begin{array}{c}\text { Station } \\
1\end{array}$} & Regression & 55.54753 & 3 & 18.51584 & \multirow[t]{4}{*}{5.73397} \\
\hline & Deviations & 54.89553 & 17 & 3.22914 & \\
\hline & Total & 110.44306 & 20 & 5.52215 & \\
\hline & \multicolumn{4}{|c|}{ - F significant at $1 \%$ level $(P<0.01)$} & \\
\hline \multirow{4}{*}{$\begin{array}{c}\text { Station } \\
2\end{array}$} & Regression & 5.76789 & 3 & 1.92263 & \multirow[t]{4}{*}{1.34645} \\
\hline & Deviations & 22.84689 & 16 & 1.42793 & \\
\hline & Total & 28.61478 & 19 & 1.50604 & \\
\hline & \multicolumn{4}{|c|}{$F$ not significant at $5 \%$ level $(P>0.05)$} & \\
\hline \multirow{4}{*}{$\begin{array}{c}\text { Station } \\
3\end{array}$} & Regression & 9.12278 & 3 & 3.04093 & \multirow[t]{4}{*}{1.83571} \\
\hline & Deviations & 26.50458 & 16 & 1.65654 & \\
\hline & Total & 35.62736 & 19 & 1.87512 & \\
\hline & \multicolumn{4}{|c|}{$F$ not significant at $5 \%$ level $(P>0.05)$} & \\
\hline \multirow{4}{*}{$\begin{array}{c}\text { Station } \\
4\end{array}$} & Regression & 1.79761 & 3 & 0.59920 & \multirow[t]{4}{*}{0.70267} \\
\hline & Deviations & 14.49681 & 17 & 0.85275 & \\
\hline & Total & 16.29442 & 20 & 0.81472 & \\
\hline & \multicolumn{4}{|c|}{ F not significant at $5 \%$ level $(P>0.05)$} & \\
\hline \multirow{5}{*}{$\begin{array}{c}\text { Station } \\
5\end{array}$} & Regression & 1.73330 & 3 & 0.57777 & \multirow[t]{7}{*}{0.41243} \\
\hline & Deviations & 22.41395 & 16 & 1.40087 & \\
\hline & Total & 24.14725 & 19 & 1.27091 & \\
\hline & \multicolumn{4}{|c|}{ F not significant at $5 \%$ level $(P>0.05)$} & \\
\hline & Variability explained & Variability u & & & \\
\hline Station 1: & 0.41524 & 0.584 & & & \\
\hline $\mathrm{S} 2, \mathrm{~S} 3, \mathrm{~S} 4, \mathrm{~S} 5$ & Regression fit & d not signific & & & \\
\hline
\end{tabular}

Table 4. Relative importance of regression coefficients

\begin{tabular}{|lccc|}
\hline \multicolumn{1}{c}{ Stations } & $\begin{array}{c}\mathrm{b} 1 \\
\text { Temperature }\end{array}$ & $\begin{array}{c}\mathrm{b} 2 \\
\text { Salinity }\end{array}$ & $\begin{array}{c}\mathrm{b} 3 \\
\text { Oxygen }\end{array}$ \\
\hline Barmouth & 0.3172 & 0.7816 & 0.0840 \\
Aroor & 0.0433 & 0.4666 & 0.0033 \\
Kumbalam & 0.0527 & 0.3479 & 0.1950 \\
Sea Lord & 0.1417 & 0.2050 & 0.4287 \\
Mulavukad & 0.0084 & 0.1915 & 0.2374 \\
\hline
\end{tabular}

saline period. Photis digitata, regarded as a low-saline species, was sampled only at barmouth (St. 1), both during low and high saline periods. Corophium triaenonyx was the most successful species inhabiting all stations and being able to tolerate wide ranges of salinity (Table 5). Shyamasundari (1972) reported the lethal salinity level of $C$. triaenonyx to be below $4 \% \mathrm{~S}$. In the laboratory she found the amphipods to be inactive at $1 \% \mathrm{~S}$. The present study shows that, though peak numbers of $C$. triaenonyx were attained at median salinities, substantial numbers were also collected at low salinities (September, Fig. 3: 1). This species seems to be quite tolerant to very low salinities over short periods of time. There is a wealth of literature, in addition to that quoted here, which documents seasonal variations in environmental parameters in and around the Cochin harbour area. Fluctuations within a tidal cycle are themselves substantial during monsoonal and post-monsoonal months. Therefore, it seems reasonable to assume that the tolerance of $C$. triaenonyx to short exposures of varying salinity is high and that this indeed is the case with the dominant species in the backwaters.

Table 5. Ranges of temperature and salinity for the more dominant amphipod species

\begin{tabular}{|lcr|}
\hline \multicolumn{1}{|c}{$\begin{array}{c}\text { Species } \\
\text { C. triaenonyx }\end{array}$} & $\begin{array}{c}\text { Temperature } \\
\left({ }^{\circ} \mathrm{C}\right)\end{array}$ & $\begin{array}{c}\text { Salinity } \\
(\mathrm{S} \%)\end{array}$ \\
\hline E. chilkensis & $26.9-30.9$ & $0.10-27.7$ \\
P. digitata & $25.5-29.8$ & $0.10-19.7$ \\
Q. bengalensis & $26.9-28.4$ & $0.90-23.8$ \\
M. zeylanica & $26.5-32.2$ & $0.10-26.2$ \\
G. gilesi & $26.5-30.0$ & $0.10-26.2$ \\
A. zamboangae & $26.0-31.7$ & $0.70-18.9$ \\
& $27.4-29.0$ & $27.70-30.6$ \\
\hline
\end{tabular}


Gravid females of Eriopisa chilkensis and Melita zeylanica were noted in good numbers $\left(2974 \mathrm{~m}^{-2}\right.$; $51666 \mathrm{~m}^{-2}$ ) from Stations 1 and 3 during October and August (Fig. 1) when the salinity was around $1.2 \%$ and $0.1 \% \mathrm{~S}$, respectively (Figs. 3: 1, 3) indicating their preference for low saline conditions during, the breeding period. Under controlled laboratory conditions $M$. zeylanica was found to breed throughout its life ( 7 to 22 broods female ${ }^{-1}$ ); the number of eggs per brood varied from 1 to 32 (Krishnan and John, 1974). Peak abundance $\left(5082 \mathrm{~m}^{-2}\right)$ of Quadrivisio bengalensis, another brackish water species, was found during the low saline $(1.2 \%$ S) period (Fig. 3: 1). However, juveniles of the species were recorded when the salinity was around $24 \% \mathrm{~S}$. Our laboratory experiments also showed maximum production of juveniles at salinities between 23 and $27 \%$ S. Grandidirella bonnieri, an euryhaline and eurythermal species (Nayar, 1956), was recorded only once from the estuary (Station 1) at medium salinities (Table 1, Fig. 3: 1). Recruitment of juveniles $\left(3125 \mathrm{~m}^{-2}\right)$ was also noted during this period. G. gilesi showed peak abundance $\left(97680 \mathrm{~m}^{-2}\right)$ of both sexes and juveniles during the low saline $(0.9 \% \mathrm{~S})$ period (Station 1).

In general, the sex ratio (Fig. 2, Table 1) showed lower values at the initial stages of population development. It increased to around 0.5 during the peak, shifting to lower or, in some cases, higher values as the population declined. The more abundant species seldom had sex ratios exceeding 0.5 .

Table 5 lists the ranges in temperature and salinity of the more dominant gammarid amphipods. They all tolerate low to median levels of salinity with Corophium triaenonyx exhibiting the widest range $(0.1$ to $27.7 \%$ S).

Temperature and salinity showed a good correlation with onset, intensity and duration of monsoon rainfalls (Fig. 4). The drop in temperature and rise in salinity in June can be attributed to intrusion of upwelled water into the estuary (Ramamirtham and Jayaraman, 1963; Sankaranarayanan and Qasim, 1969). This feature was apparent at the barmouth, less so at stations inside the estuary (Fig. 4).

Table 6. Correlation of families with temperature, salinity and oxygen

\begin{tabular}{|lrrc|}
\hline \multicolumn{1}{|c}{ Family } & Temperature & Salinity & Oxygen \\
\hline Ampeliscidae & $0.8083^{\circ}$ & $-0.98676^{*}$ & 0.7784 \\
Gammaridae & $-0.41513^{*}$ & -0.28374 & -0.0123 \\
Corophidae & $-0.04435^{*}$ & $0.13593^{*}$ & 0.10805 \\
Photidae & $-0.58115^{*}$ & $-0.60084^{*}$ & -0.47798 \\
& & \\
Significant at $5 \%$ level $(\mathrm{P}<0.05)$ & \\
\hline
\end{tabular}

During the period of occurrence of gammarid populations the organic carbon and nitrogen content of sediments were in general high 7.40 to $38.40 \mathrm{mg} \mathrm{g}^{-1}$ and 0.90 to $5.7 \mathrm{mg} \mathrm{g}^{-1}$, respectively (Sankaranarayanan and Panampunnayil, 1979). These authors also observed major portions of phosphorous in the sediments of the area investigated to be of abiogenic origin and attributable to pollution due to sewage disposal and harbour activities. Remani et al. (1980) further observed that the influence of waste discharge in the harbour area results in high organic carbon and $\mathrm{C} / \mathrm{N}$ ratios in sediments. This, however, seems to have no influence on the gammarid populations.

Coefficients of correlations over time revealed significant relations between Photis digitata and environmental characteristics. The relation was positive with temperature, dissolved oxygen and $\mathrm{C} / \mathrm{N}$ ratio, and negative with salinity, organic carbon, nitrogen and phosphorous $(\mathrm{P}<0.001)$. Positive correlation was observed between $P$. digitata and nitrogen content of sediments $(\mathrm{P}<0.05)$ and between adults of Corophium triaenonyx and phosphorous $(\mathrm{P}<0.05)$.

The coefficient of correlation matrix (Fisher and Yates, 1963) showed that $69.91 \%$ of the correlations between species were positive and $40 \%$ were highly significant at the $0.1 \%$ level $(P<0.001$ ) (Table 2 ). The coefficient of correlations calculated with variables such as temperature, salinity and dissolved oxygen showed that none of the groups were significantly correlated with salinity, temperature and dissolved oxygen, except members of the family Ampeliscidae at the $5 \%$ level $(\mathrm{P}<0.05)$ (Table 6$)$.

The relative importance of physico-chemical parameters revealed that salinity was the prominent factor controlling the abundance of gammarid amphipods, followed by temperature and dissolved oxygen at Stations 1 and 2. At Stations 4 and 5 oxygen was a prominent factor, followed by salinity and temperature. At Station 3 salinity was a prominent factor, followed by dissolved oxygen and temperature. Again, the ' $F$ ' test revealed significant differences between Stations 1 to $5(\mathrm{P}<0.05)$ (Table 7$)$.

Table 7. Anova table for testing difference between stations

\begin{tabular}{|lrrrr} 
& \multicolumn{1}{c}{ Source } & DF & MSS & F \\
\hline Total & 194.11397 & 54 & & \\
Between stations & 63.79375 & 4 & 15.94844 & 6.11894 \\
Error & 130.32022 & 50 & 2.60641 & \\
Calculated F significant at 5\% level & & \\
\hline
\end{tabular}

From the normal equations the regression coefficients $b_{0}, b_{1}, b_{2}, b_{3}$ were calculated. The equations of fitted regressions were: 


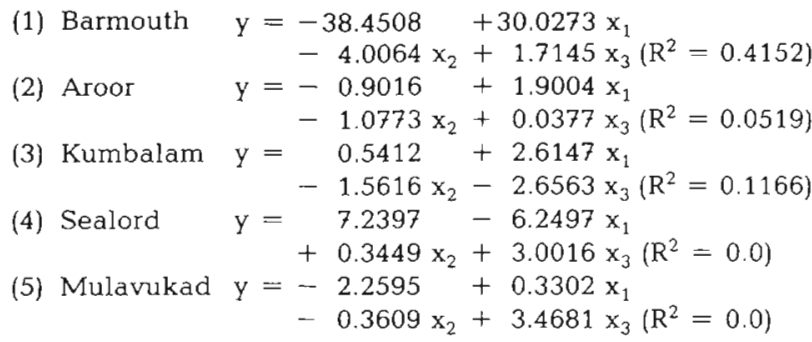

Table 3 indicates that fitted regression was significant only for Station 1 at the $1 \%$ level $(P<.01)$. The fitted model, however, was capable of explaining a significant part of the variability in the abundance of gammarid amphipods. The variability explained by the regression model was $42 \%$. The variability unexplained by the regression model may have been due to other variables not included in the model (Snedecor and Cochran, 1967) - such as biological factors, current, turbidity, depth, stratification, phosphate, nitrate, etc. Table 2 shows that $69.91 \%$ of the species coexisted while the remaining species occurred alone. Table 8

Table 8. Fisher's diversity index and its variance $V(\alpha)$

\begin{tabular}{|rrrll|}
\hline Stations & $N$ & $S$ & \multicolumn{1}{c}{$\alpha$} & \multicolumn{1}{c|}{$\mathrm{V}(\alpha)$} \\
\hline 1 & 1398122 & 11 & 0.720097 & 0.000024492 \\
2 & 4480 & 3 & 0.3135703 & 0.00296078 \\
3 & 21684 & 4 & 0.2861164 & 0.0001177033 \\
4 & 8030 & 4 & 0.4041686 & 0.00353885 \\
5 & 715 & 3 & 0.337560 & 0.00375683 \\
\hline
\end{tabular}

indicates that $\alpha$ ranged from 0.286 to 0.720 which showed that there is no significant difference in the environment at the different stations. A higher number of species with a lesser number of individuals at Station 1 than at the other stations indicates that the environment at Station 1 is 'older'. Low values for $\alpha$ (diversity index) indicate that the environment at those stations may be 'new', 'severe' or unpredictable. The variance of $\alpha[\mathrm{V}(\alpha)]$ ranged from 0.00002 to 0.00376 . This showed that calculated values of $\alpha$ were stable for all the stations.

Acknowledgements. The authors are extremely thankful to Dr. V. V. R. Varadachari, Director, National Institute of Oceanography, Goa, for providing facilities to carry out this work and to Dr. S. Z. Qasim, Secretary, Department of Ocean Development, New Delhi for constant encouragement. Thanks are due to Dr. M. Krishnan Kutty, Scientist-in-Charge, Regional Centre of NIO, Cochin, for his interest and valuable suggestions in this study and to Shri K. H. Krishna Iyer, Scientist, Central Institute of Fisheries Technology, Cochin, for valuable suggestions regarding statistical analyses

\section{LITERATURE CITED}

Fisher, R. A., Corbet, A. S., Willians, C. B. (1943). The relation between the number of species and the number of individuals in a random sample of an animal population. J. Anim. Ecol. 12: 42

Fisher, R. A., Yates, F. (1963). Statistical tables for biological, agricultural and medical research, Oliver and Boyd, London

Haridas, P., Madhupratap, M., Rao, T. S. S. (1973). Salinity, temperature, oxygen and zooplankton biomass of the backwater from Cochin to Alleppey. Indian J. mar. Sci. 2: 94-102

Krishnan, L., John, P. A. (1974). Observations on the breeding biology of Melita zeylanica Stebbing, a brackish water Amphipod. Hydrobiol. 44: 413-430

Nair, K. K. C., Tranter, D. J. (1971). Zooplankton distribution along salinity gradient in the Cochin backwater before and after the monsoon. J. mar. biol. Ass. India 13: 203-210

Nayar, K. N. (1956). The life history of a brackish water amphipod Grandidierella bonnieri Stebbing. Proc. Indian Acad. Sci. B-43 (3): 178-189

Qasim, S. Z., Gopinathan, C. K. (1969). Tidal cycle and environmental features of Cochin backwater. Proc. Indian Acad. Sci. 69: 336-348

Ramamirtham, C. P., Jayaraman, R. (1963). Some aspects of the hydrographical conditions of the backwaters around Willingdon Island (Cochin). J. mar. biol. Ass. India 5: $170-177$

Remani, K. N., Venugopal, P., Saraladevi, K., Lalitha, S., Unnithan, R. V. (1980). Sediments of Cochin backwaters in relation to pollution. Indian J. mar. Sci. 9: 111-114

Sankaranarayanan, V. N., Panampunnayil, S. U., (1979). Studies on organic Carbon, Nitrogen and Phosphorous in Sediments of the Cochin backwater. Indian J. mar. Sci. 8: $27-30$

Sankaranarayanan, V. N., Qasim, S. Z. (1969). Nutrients of the Cochin backwater in relation to environmental characteristics. Mar. Biol. 2: 236-247

Shyamasundari, K. (1972). Studies on the tube building amphipod Corophium triaenonyx Stebbing from Vizakhapatnam Harbour. Annual Life Cycle. Riv. Biol. 25: $503-516$

Snedecor, G. W., Cochran, W. G. (1967). Statistical methods, Oxford \& IBH, Publishing Co., Calcutta

Strickland, J. D. H., Parsons, T. R. (1968). A practical handbook of sea water analysis. Bull. Fish. Res. Bd Can. 167 